\title{
BERNARD BOLZANO'S PHILOSOPHICAL CONCEPTION OF EDUCATION FROM A MODERN STANDPOINT
}

\author{
ANDRII SYNYTSIA \\ Faculty of Philosophy, Ivan Franko National University of Lviv \\ Universytetska 1, Lviv, Ukraine \\ E-mail: andrii.synytsia.edu@gmail.com \\ ORCID: https://orcid.org/0000-0002-0983-7187
}

\begin{abstract}
Aim. The aim of the article is to analyse Bernard Bolzano's philosophico-educational approach, given the importance of his pedagogical legacy for further progress in the field of education and training.

Methods. The research uses methods of historico-philosophical reconstruction (to determine the foundations and features of Bolzano's pedagogico-philosophical work), interpretation (to characterise the still relevant ideas of the thinker in the field of education) and critical analysis (to assess the significance of Bolzano's legacy from the standpoint of modern educational theory and to point out what remained out of the researchers' attention).

Results. The study showed that Bolzano's pedagogical ideas were not only in demand in the context of European culture of the early XIX century, but also proved relevant today, especially given the need for harmonious personal development, finding sources of intrinsic motivation in students and improving their logical thinking skills, the importance of the spiritual qualities of the teacher and - in general - the assistance of the state in the direction of the progress of education as the most effective means of qualitative change in society.

Conclusion. Bernardo Bolzano's philosophical conception of education was strongly influenced by religion, the ideas of the late Enlightenment and the late Josefinist. This conception was an integral part of his socio-political theory. Bolzano attached great importance to the study of philosophy and the acquisition of logical skills in education. He considered writing textbooks to be one of the cornerstones of the educational process. This made it possible to intensify communication between teachers and students, to gradually involve everyone in education, and thus to promote social progress in general.
\end{abstract}

Key words: philosophy of education, logic, textbook, communication between teacher and students, Bernard Bolzano's pedagogical ideas. 


\section{INTRODUCTION}

$\mathrm{B}^{\mathrm{e}}$ rnard Bolzano (1781-1848) is best known for his groundbreaking ideas in mathematical logic, scientific semiotics, logical semantics and heuristics. Most of them remained unknown for a long time and were rediscovered with the development of science and philosophy in the twentieth century. The depth of these ideas gave rise to Dagfinn Føllesdal in the late twentieth century to boldly say that Bolzano 'was one of the most important thinkers of his time and one of the most universally talented philosophers (...)' (Føllesdal, 1997, p. 1). Michael Beaney considers Bolzano as one of the forerunners of analytic philosophy, and - among the main events of its early history - he includes the appearance of his 'Contributions...' (1810), which contained a critique of Kant's distinction of a priori/a posteriori, the four-volume 'Theory of Science' (1837) and 'Paradoxes of the Infinite' (1851), which anticipates meaningful ideas of a later set theory (Beaney, 2013, pp. 67-69).

Considering that the 'Gesamtausgabe' project to publish Bolzano's legacy is still ongoing (see: Bolzano: Gesamtausgabe, 1969ff) and that many volumes await publication, it is clear that the impact of his ideas will be even greater, not only in logic. This is mostly emphasised by researchers such as Peter M. Simons (Simons, 2013) or Ettore Casari (Casari, 2016). Also, his impact is visible in the field of socio-political life, and especially in pedagogy, the theoretico-philosophical aspects of which he has been actively developing since he started teaching at the University of Prague. However, there is still no proper assessment of his legacy in the field of philosophy of education, which is mostly seen as part of his socio-political theory (Sirưček \& Šetek, 2019). Notably, the ideas of pedagogy are essential in his 'Theory of Science' (Bolzano, 1837) and in the liberal theory of the ideal state (Bolzano, 2007), or even in philosophical conception (see, for example: Bolzano, 1849).

To analyze Bernard Bolzano's views on education (especially teaching and upbringing) from a modern philosophical perspective, it will be clarified under what conditions his philosophical conception of education was formed, what place the learning process occupied in the social life, what pedagogical tasks of philosophy and logic he singled out, and how he characterised the main ways of presenting knowledge in the textbooks, as well as what the key features of communication between teacher and students were.

\section{SOCIO-POLITICAL BACKGROUND OF THE PHILOSOPHICAL CONCEPT OF EDUCATION}

To characterise the sources of Bolzano's philosophy of education, several things need to be considered. Firstly, it should be noted that religion played an essential role in his life: he came from a family of Prague priests and was brought up in a religious spirit; in particular he attended Piarist Gymnasium in Prague (1791-1796), and then he became a student at Charles University of Prague, where he first studied philosophy, logic and mathematics, and finally, 
in 1800-1804, he became a theologian. After that, at the same university, Bolzano began his teaching career, combining his interests in philosophy and theology with mathematical studies. The choice of profession of the theologian seemed to him more perspective in comparison with mathematics, considering the possibility to influence education of youth by means of public speeches (Bolzano, 1836). He delivered about a thousand such speeches (known as Sunday sermons). They concerned topical social, political, educational and religious issues of the time and had a significant impact on the formation of the worldview of young people and the awakening of the Czech national consciousness (Bolzano, 1887).

Secondly, Bolzano's own views were influenced by the philosophical ideas of the late Enlightenment. He was firmly convinced of the power of logic and reason; he emphasised the interpretation of philosophy as a means of intelligent upbringing and education, and he pointed to the need for rational restructuring of society and the establishment of civil rights and human freedoms. Bolzano learned many of his enlightenment ideas from the representatives of the so called Leibniz-Wolf school, especially from Immanuel Kant. However, despite the popularity of Kantianism, Bolzano expressed critical views about it. In particular, in the first book of 'Theory of Science' ('Theory of Fundamentals'), he criticised the concept of truth itself, and argued that the truth can be known. And if so, then Kant's agnosticism is wrong, and his division of judgments into analytic and synthetic ones should be considered clearly incomplete (see also: Bolzano, 1837, §148). In addition, Bolzano singled out logico-analytic judgments, the meaning of which depends on their non-logical elements (see also: Dubislav, 1929). In this critique of Kant's views one can also see the formation of ideas of non-classical philosophy, manifested in the search for new approaches to solving traditional philosophical problems, analysis of the paradoxes of the infinite, beyond the rational paradigms of reality (Bolzano, 1950). This criticality was also one of the theoretico-methodological principles in the field of education, because the teacher always had to clearly check the validity of knowledge before teaching it to others. Only rational arguments were recognised as worthy of being communicated to others in the learning process.

At the same time, the formation of Bolzano's worldview was influenced by the socio-political order of the Habsburg monarchy, which firmly established its position in Central and Eastern Europe. He was impressed by the ideas of late Josefinist, according to which the implementation of social reforms was possible through education, and therefore through rational arguments and logical conclusions. It was essential to him that the truths of religion were understood. As Pavel Sirůček and Jaroslav Šetek note: '[Bolzano] sought the legitimacy of religious beliefs by advocating moral benefits through pragmatic arguments' (Sirůček \& Šetek, 2019, p. 99). Such pragmatism was obviously due to the intention, on the one hand, to preserve and improve the moral order of society, and on the other hand, to influence intellectual circles with realistic and rational arguments. Of course, such a pragmatic approach was due to the need to combine the rank of priest and the work at a state university. 
This was not always approved by officials and clerics. In fact, it was principal for Bolzano to teach the ideals of social justice, freedom and equality and to uphold the ideas of abstract humanism and utopian socialism, and the attempts of social equality by officials were perceived as revolutionary and as a rejection of state-approved university standards. In turn, the clergy expected him to more actively defend the usual spiritual ways of life, where it was not always possible to combine the achievements of technological progress and science. Bolzano, on the contrary, interpreted religion as inseparable from the truths of reason. In 1819, Bolzano's reformist views led to his dismissal from the University of Prague (Sirůček \& Šetek, 2019, p. 96) with a subsequent prohibition on public administration, public speaking, and publishing. However, this did not prevent him from further uniting of creative youth around his ideas, finding new supporters, and influencing the philosophical ideas of later thinkers - in particular Edmund Husserl (Huemer, 2004), Kazimierz Twardowski (Simons, 2013, p. 15; Synytsia 2013, p. 146), Franz Brentano, Tomas Masaryk and other supporters of the Austrian philosophical tradition that influenced the scientific worldview of Ludwig Wittgenstein, Otto Neurath, and Karl Popper (Zdenek, 2008).

\section{EDUCATION AND THE STATE}

The interest in his ideas was facilitated not only by their depth, but also by Bolzano's pedagogical skills and the clear understanding of the place of education in the life of the state. Without the understanding of the direction in which the state is develops, it would obviously not be clear what knowledge to teach students. However, his theory of the state as a whole was somewhat utopian. He believed that too many spheres of public life could be regulated by the state and, at the same time, that the society may preserve internal freedom in the decision-making process. For instance, Bolzano considered the general welfare (i.e., the common good of the community) as a criterion for how much property a person needs to have privately (Bolzano, 2007b, p. 288). In other words, as long as a person's private property benefits the community, that right is a guaranteed public value. However, a person may be deprived of the right to own the thing, which, on the one hand, is clearly superfluous and invaluable for them, but, on the other hand, may be needed by other people. This is of course somewhat paradoxical. However, in the realities of the time when ordinary people were only beginning to realise their power and fight for political rights, such statements could impress them. From the standpoint of our time, as Paul Rusnock and Rolf George note, this kind of reasoning could be useful at least in showing the horizon of possibility for an intelligent, educated human at the time (Rusnock \& George, 2007, p. 39). However, given the field of education, these considerations have some value in the view of their prospects. At least in the pedagogy theory, Bolzano was quite clear and consistent in his statements and expressed a number of advanced, both practical 
advice and logico-philosophical, reflections. In any case, it is important that Bolzano intended to consider life in the society as a whole and to demonstrate the place of education in it.

According to his conception, the education of the younger generation (his recommendations generally applied to children who are still learning to read and write, as well as university students and scientists in general, who should also learn to teach in a new way) is one of the key functions of the state. And the better the social order in the state, the better the youth will be educated. However, to achieve this, the state needs education and enlightenment. Educated people are the first to contribute to positive change in the state. Without an appropriate level of citizens' education, nothing can be properly reformed in the state, because people will not understand certain things and will not be convinced of their need. Under such conditions, they will distrust everything that happens. When there is understanding, trust and a sense of duty are often formed. Therefore, the first - and at the same time the most strategic - reform in the society is the reform of education. This reform, of course, should not be the only one, but it is enough to initiate positive changes in the society.

\section{ON THE PEDAGOGICAL STRATEGY OF PHILOSOPHY}

Bolzano assigned a special task in the correct upbringing of young people to philosophy and its integral component - logic. Knowledge of philosophy allowed the researcher to correctly understand the deep foundations of existence, and therefore to formulate the correct view of things. Bolzano defined philosophy not as worldview knowledge, but as a science that has its own subject of study and clear methodology. According to Bolzano, to start philosophizing, everyone needs to ask 'Why?' In this way, the researcher's attention will be focused directly on the causes of things. At first glance, the definition of philosophy through the prism of the study of principles is entirely in the spirit of Aristotle's metaphysics. However, it was essential for Bolzano to interpret philosophical reflections not as a set of abstract speculations, but as more applied knowledge. Given this, philosophical thought will concern not only the question of God, the world as a whole, the ontological dimensions of good and evil or the possibility of knowing the truth, but also those things that have a more practical application - for instance, history, natural science, music, and especially education. After all, as Bolzano explained: 'Philosophy is the science of the objective interrelations of all such truths, into the deepest grounds of which, as far as possible, we make a task to penetrate in order to become wiser and better' (Bolzano, 1849, p. 30). To make a person 'wiser and better,' a philosopher must set a number of pedagogical goals: to formulate their own ideas clearly and understandably for other people, to teach them, and to instill in students (more broadly - readers) a sense of responsibility to the community. The thinkers themselves must understand the needs and interests of their audience and teach people those ideas that will strengthen the moral order of society (Bolzano, 1850). 
It is important that not only the philosophers themselves but also every other person improves. At the beginning of the path of knowledge, these basics are not yet clear. That is why we need a teacher - they will be able to show the right way to know these philosophical basics. Society as a whole must realise the value of moral knowledge. In this case, the community will be able to build an order in the state and guarantee the observance of law, and the study of philosophy will become a conscious spiritual need. That is why Bolzano, among the five basic sciences that make up the core of philosophy, in addition to logic, metaphysics and ethics, also called the doctrine of law and the science of the state (Bolzano, 1849, p. 18-19). Logic allows us to know the truth correctly, metaphysics clarifies what underlies things, knowledge of morality affects the inner world of human and their actions on the basis of moral responsibilities, and finally, the doctrine of law and the science of the state (ways of organizing people in it) contribute to understanding how to make all members of the society as happy as possible.

In essence, Bolzano's ethics was not only principally rationalistic, as Helena Lorenzová remarks (Lorenzová, 1998), but also influenced by utilitarianism. Even in 'Treatise of the Science of Religion' (1834), he defined supreme moral law as follows: 'Strive to bring about the greatest possible sum of happiness' (Bolzano, 2007, p. 216). An important condition for achieving happiness is both knowledge of the nature of the external world and internal spiritual development. Bolzano clearly realised that these things were interconnected. When people understand how to act in certain situations, on the basis of which rules can be achieved optimal results, when they are able to predict the consequences of their actions and realise them, they certainly become more morally perfect. Honesty and decency is simply a more logical strategy of behavior in a society where it is appropriate to take into account the interests and needs of different social groups and individuals. At the same time, a human, being full of kindness and compassion for others, will understand that in order to make the right choice in life, they must understand what human life is like in this world and what this world (macrocosm) and human (microcosm) as part of it are like.

For Bolzano, philosophical research within the five sciences was an analysis aimed at acquiring new truths. It is impossible to know these truths without following the rules of logic and moral improvement of human themselves as a member of society.

\section{LOGIC AS THE MAIN TOOL AND PURPOSE OF LEARNING}

Bolzano believed that improving scientific results and enhancing pedagogical skills can be done through the study of logic and the ability to apply it in practice. On the one hand, logic is the key to the study of other sciences, on the other hand, it is the most scientific means of persuading the audience. Logic makes it possible to improve thinking, just as grammar makes it possible 
to improve word usage. A student who has mastered logic will be much less likely to err in the process of reasoning, and therefore will make erroneous conclusions much less often (Bolzano, 1837, 1, § 9), even in spite of the novelty of the situation.

For Bolzano, logic is not a completely independent science, because the procedure of justification is not always exclusively formal. We operate with different ideas and knowledge. To understand how certain facts were obtained, you need at least knowledge of psychology (Bolzano, 1837, 1, § 13). It is important to understand how the process of acquiring knowledge or a set of true judgments takes place, because, as life experience shows, a person cannot always be convincing to others simply because he or she uses logical arguments. Psychological means also play a significant role in the process of persuasion. They are an integral part of persuasion and form a pragmatic context of expression. Sometimes this context is full of nonverbal meanings that may not always be clearly expressed on a formal level. Nevertheless, logical theory clearly indicates their presence.

In Bolzano, logic ceases to be a mere formal theory aimed at studying the forms and laws of thought, even though it is a science whose purpose is to formulate rules, 'according to which we must proceed in the business of dividing the entire realm of truth into single sciences and in the exposition thereof in special textbooks if we want to proceed in a truly expedient fashion' (Bolzano, $1837,1, \S 7$ ). Logic is both the art of discovery (heuristics) and the theory of science. It is essential for Bolzano in the course of logic to demonstrate that there are truths in themselves that we can know, and that we are able to formulate true propositions and derive new truths from them. He intended to determine the conditions for knowing the truths, to teach the rules that must be followed in order to discover new truths and present them in textbooks.

Thus, having mastered the basics of logic, the student will master a certain set of rules. Proper application of these rules leads to the formation of knowledge (consistency of propositions with the truth). But the consequence of refusing to apply the rules is ignorance and the person simply ceases to have the concept of something. If the rules in the process of cognition are applied incorrectly, the resulting judgments will differ from the truth. The practice of rule-following improves the minds of learners and allows them to get closer to the causes of things. If a person understands these causes, the knowledge will become clear to them (Bolzano, 1837, 3-4, § 311) and the logic will be interpreted as 'the way to go about inventing the truth' (Bolzano, 1837, 3-4, § 322).

Analyzing the rules that Bolzano defined as the main ones in the process of discovering new truths, it is easy to notice the influence of his own pedagogical practices on the chosen philosophical strategy. He suggested starting the search for truth with a clear question, breaking a complex question into a set of simpler ones and, if possible, deducing the unknown (Quasitum) from the data (Datum). If necessary, it is advisable to use the hypothesis testing method, induction, analogy, or combine them all together. In the process of solving the problem, it is necessary to take into account the pragmatic context of propo- 
sitions, check the data and results, to be as accurate as possible in formulations, to create visual images to express the conditions of the problem, to be as consistent as possible, and to cover all possible logical relations between task data. In this case, the scientist will be able to find a new truth (Bolzano, 1837, $3-4$, § 325-348). As we can note, the search for truth, according to Bolzano, resembles the process of solving a problem in school, when the student must gradually move from what is given to what is unknown. Under more complex conditions, you will have to take into account both general and special rules ('defondere regeln'), as well as the specifics of a particular task. In general, all these rules are universal and will be useful for the student in later life: they will present everything that will be incomprehensible to them in the form of a task, and they will successfully solve it on the basis of the method proposed by Bolzano.

\section{WRITING A TEXTBOOK AS THE TOP OF THE THEORY OF SCIENCE AND THE BASIS OF THE EDUCATIONAL PROCESS}

Bolzano was convinced that the rules of logic should be applied not only to divide truths into particular sciences, but also to formulate them within a particular textbook. If we consider the fact that the final (fifth) part ('Eigentliche Wissenschaftlehre') of 'Theory of Science' (§ 392-712) explains how to teach science in textbooks, it becomes clear that what he considers the peak of the development of the theory of science is the ability to teach it to others. The teacher can talk a lot and teach a lot, but if the thoughts are not clearly stated in the textbook, they will be of little effectiveness. Writing a textbook is also essential so that the ideas expressed by scientists were not unnoticed by contemporaries and did not have to be rediscovered later. The sooner these ideas are understood and developed by others, the sooner they can benefit society and multiply the common good.

Bolzano focused on the textbook, not, for example, on oral presentations to the audience, because it mattered for him to make sure that students could learn on their own, that is, when there is no teacher nearby. The textbook to some extent replaced the teacher. In general, each book can be considered as a textbook from which everyone can take some knowledge. However, there are important requirements for writing the actual textbooks that are used in the educational process. Bolzano pointed out that every science should have its own textbooks. They will not include all the truths that are within a particular science, but only those that will allow the student to get a clear idea of its research subject. The author of the textbook must choose the truths that are most crucial given the theoretical and practical significance of this science in the society. To make the choice of the most significant truths, the author must undoubtedly be a professional in their field. However, to write a textbook, they must also have the appropriate skills to work with students. It is necessary to understand not only what to write in the textbook, but also for whom, because 
it depends on the reader what didactic techniques the author should use to convincingly formulate each opinion.

It is impractical to write a textbook for those who will not be able to understand its content or to agree with it. The author should make the ideas presented in the textbook as clear as possible for the reader. In other words, they should clarify what was unknown to the reader in the most understandable way. This cannot be achieved without taking into account readers' interests (Bolzano, 1837, 3-4, § 399). If this is not done, the textbook will not be of much interest or confidence. On the other hand, the less subjectivity there is in the book, the more convincing it will seem. At the same time, it is important for the author not only to present objective truths, but also to demonstrate each time how they were obtained and what are the connections between these truths. In this way, the reader will be able to check the correctness of the propositions in the textbook and verify their truth. The author should anticipate possible doubts on the part of the reader about the content of the textbook, and try to answer them to reduce distrust of the truths presented.

In order to be as convincing as possible, the teacher must select the correct propositions in the textbook, regardless of whether they are basic, auxiliary, or accidental. Each of these propositions is significant in the process of presenting scientific knowledge: both to understand the essence of science at the theoretical level and to point to its practical significance. Comparisons, distinctions, definitions, descriptions, various kinds of proofs (progressive, regressive, mixed, by reduction to absurdity, through induction and analogy, on the basis of pure concepts or experience), remarks and refutations, examples, classification subdivisions (Eintheilungen), etc. are suitable for this purpose. Moreover, in order to make the purpose of the textbook more understandable to readers, it is appropriate to divide it into sections (Bolzano, 1837, 3-4, § 580). It is also not superfluous to present the material in order to move from general to special, from simple truths to complex ones, or from theoretical (conceptual, general) knowledge to empirical statements (practical, specific).

In order to improve comprehension, it will also be advisable to use various symbols, or signs (Zeichen). As science is constantly evolving, it is essential to introduce new signs (terms). By applying them, it will be possible to more clearly capture the actual correlations between things, and the scientists themselves will be able to express their opinion more accurately. The signs used in textbooks should be as simple as possible in appearance, convenient for both the reader and the author, and similar to the subject they denote. This will make them easier to remember and use in ordert to understand known truths and find new ones. By developing these basics of pedagogical semiotics, a scientist can achieve even greater clarity in the process of studying their subject. As we can see, even though Bolzano defined the semiotics (Zeihenlehre) as 'the doctrine of signs, some of which should be suggested in the textbook and some of which should be used' (Bolzano, 1837, 3-4, 7th ch., p. 500), he was one of the first in history to develop the ideas of a particular doctrine of signs and filled it with clear pedagogical content and didactic expediency. 


\section{TEACHER AND STUDENT COMMUNICATION}

However, it cannot be said that Bolzano focused his attention exclusively on the textbook. As an experienced teacher and educator, he understood that the educational process is defined by the teachers and students. According to Bolzano, it depends on the teacher to what extent students will be able to acquire practical skills and theoretical knowledge, and it depends on the interests of students and their needs to what extend they will be willing to work selflessly and improve their skills.

Based on a comprehensive analysis, Bolzano described the strengths and weaknesses of the teacher. He was convinced that certain moral shortcomings of the author themselves have a negative impact on the process of teaching science. Among such shortcomings Bolzano included: incomprehensible ('Dunkels') presentation of science, the author's complacency ('Selbstgefälligkeit') (it is manifested in the self-confident belief that everything he or she writes is extremely important); vanity ('Eitelkeit'), the desire to arouse excessive reverence (Ehrfurcht) for one's own work and arrogance ('Hochmut') towards other similar works (Bolzano, 1837, 3-4, § 700). Bolzano rightly believed that until the authors themselves became good humans, they cannot become true professional scientists or brilliant teachers.

In general, among the basic qualities of a teacher Bolzano distinguished good morals (primarily in order to teach students to be fair and honest), common sense (which is needed to solve public, practical matters, to distinguish right and wrong, to give convincing examples in specific situations, etc.), cheerfull disposition (for the ability to resolve conflict situations and create a favorable atmosphere of trust and respect in the team), love of his profession (which is manifested in particular in the intention to improve), and knowledge of how his teaching should proceed (because for both teachers and for students, it is essential to know in which direction the students could develop further the acquired skills, when they leave the school and there is no teacher nearby) (Bolzano, 2007b, p. 280-281).

In fact, the teacher must have a good understanding of who the students are. After all, it is one thing to teach elementary school students, and another -to teacg high school students or students who no longer seek for general knowledge, but wish to acquire special skills. In the first case, learning should be based on the principle of diversity and it is crucial that students are shown the truths of different sciences. This will make the child's mind glad, open to a variety of sciences, among which everyone can find something of their own. The subjects taught at school concern the development of the ability to use one's own senses and the ability to think logically; the exercise to promote health and, if necessary, to help others when they are in danger; the most rational, according to officials, religion; natural history, hygiene and medicine; arithmetic, geometry, mechanics, and natural science; astronomy. Also, students should master reading and writing, singing (if available), should know their native language and other ones to communicate with other nations, some 
of the history, law and the laws of the state, some handcraft (Bolzano, 2007b, p. 279-280). Of course, not everything can be fully learned at school, for example, medicine. But even general knowledge can help the patient to describe his health more accurately. And this can make it easier for the doctor to find the causes of the disease. In the future, students will be able to develop their skills in higher schools, where they will learn a little more than in elementary and holiday schools. However, it is not the principles of education which will actually change much, but rather life challenges and realities, as well as professional interests will change.

It is important to consider the interests of the students in order to understand what they look for in the book. If students want to exhaustively study a certain topic, they need the same textbooks as scientists. If a person studying a certain topic uses the truths represented in the book in everyday life for the sake of professional growth, the teacher must consider these interests and focus on them. Of course, in many cases the interests of a potential reader can be very common. They will be interested only in those information that can be used later in life. The teacher must understand the needs of students (readers) and try to present in the textbook those truths that could contribute to their spiritual growth, and thus benefit the community (Bolzano, 1837, 3-4, § 430).

One should bear in mind that learning is not limited to teacher-student communication in the classroom. According to Bolzano (2007b, p. 283), sound learning is not possible without libraries, where students can find all the necessary literature - to deepen their theoretical and practical experience, to strengthen faith, or to improve their learning skills, as well as to read something new about the world, the state, and its laws. However, it is essential that the books available in the library do not interfere in any way with the moral improvement, because without it the student will not be able to clearly understand their social responsibilities and their own vocation. These books should definitely be available to everyone, even though only a few will become real professional scholars, i.e., people for whom the production of scholarly works is the main occupation (Bolzano, 2007b, p. 316). In any case, success in science, as well as in other spheres of public life, will depend on the state, which should provide appropriate conditions for each participant in the educational process.

\section{CONCLUSIONS}

Taking everything into account, it can be argued that the Bolzano's philosophical conception of education was not only full of certain trends of the Enlightenment, but also contained some new pragmatico-analytic and practical elements. It was important for him to make the educational process as effective and useful as possible for the state as a whole and for students and teachers in particular. He considered education as an integral part of the society and a guarantee of the progress and prosperity of the state. Bolzano paid much attention to the analysis of each element of education and the characteristics 
of both those who teach and those who learn. He clearly understood the purpose of education (i.e., increasing the common good in the state). This purpose determined the nature of his philosophico-pedagogical reflections. Bolzano had special hopes for the formation of logical skills in students, because he interpreted logic as a universal means of cognition and a prerequisite for the acquisition of various skills. At the same time, he emphasized the need to improve professional skills, for which he placed special emphasis on, and to writing textbooks that would be a source of knowledge for students in the learning process, both under the guidance of a teacher and independently. With practical teaching experience, Bolzano understood that education would be ineffective without quality textbooks and libraries, without the charisma of the teacher and without his or her love for the chosen profession, without the gradual learning of students from early childhood, without government assistance and opportunities to further implement acquired skills in community life. If, on the contrary, the educational process is carried out in a balanced and scrupulous way, it is possible to reform not only education but also other spheres of social life and to achieve social progress.

\section{REFERENCES}

[1] Beaney, M. (2013). Chronology of Analytic Philosophy and Its Historiography. In: M. Beaney (Ed.), The Oxford Handbook of The History of Analytic Philosophy (pp. 61-140). Oxford: Oxford University Press.

[2] Bolzano, B. (1810). Beyträge zu einer begründeteren Darstellung der Mathematik 1. Prag: Widtmann.

[3] Bolzano, B. (1836). Autobiographie des Dr. B. Bolzano. In: Lebensbeschreibung des Dr. B. Bolzano mit einigen seiner ungedruckten Aufsätze und dem Bildnisse des Verfassers eingeleitet und erläutert von dem Herausgeber (pp. 1-88). Sulzbach: J. F. Seidelschen Buchhandlung.

[4] Bolzano, B. (1837). Wissenschaftslehre. Versuch einer ausführlichen und größtentheils neuen Darstellung der Logik mit steter Rücksicht auf deren bisherigen Bearbeiter. Sulzbach: J. E. v. Seidel. 4 Bde.

[5] Bolzano, B. (1849). Was ist Philosophie? Vienna: Wilhelm Braumüller.

[6] Bolzano, B. (1850). Über die Vaterlandsliebe. Dr. Bernard Bolzano's Erbauungsreden an die akademische Jugend. Bd. 2 (pp. 145-156). Prag: Heß.

[7] Bolzano, B. (1887). Řeči vzdělávaci akademické mládeži. Praha: Fr. A. Urbánek.

[8] Bolzano, B. (1950). Paradoxes of the Infinite. D. A. Steele. (trans.). London: Routledge.

[9] Bolzano: Gesamtausgabe (1969ff). Critical edition. E. Winter, J. Berg, F. Kambartel, B. van Rootselaar (Eds.), Stuttgart: Fromman-Holzboog. Retrieved from: https:/ /www.frommann-holzboog.de/editionen/20?lang=en-gb.

[10] Bolzano, B. (2007a). Natural Morality / Treatise of the Science of Religion, part 1, §§ 86-95, In: Bernard Bolzano, Selected Writings on Ethics and Politics (pp. 199-229), P. Rusnock, \& R. George (trans.). Amstermam; New York: Rodopi.

[11] Bolzano, B. (2007b). The little book on the best state or Thoughts of a friend of mankind on the most suitable institutions for civil society. In: B. Bolzano. Selected Writings on Ethics and Politics (pp. 235-356). P. Rusnock, \& R. George, (trans.). Amstermam, New York: Rodopi.

[12] Casari, E. (2016). Bolzano's Logical System. Oxford: Oxford University Press.

[13] Dubislav, von W. (1929). Lieber Bolzano als Kritiker Kants. Philosophisches Jahrbuch, 42, 357-368.

[14] Føllesdal, D. (1997). Bolzano's Legacy. Grazer Philosophische Studien, 53(1), 1-11.

[15] Huemer, W. (2004). Husserl's critique of psychologism and his relation to the Brentano 
school. In: A. Chrudzimski, \& W. Huemer (Eds.), Phenomenology and Analysis: Essays on Central European Philosophy (pp. 199-214). Berlin: Walter de Gruyter.

[16] Lorenzová, H. (1998). Bernard Bolzano - Pedagogue. The Paideia Archive: Twentieth World Congress of Philosophy, 43, 89-92.

[17] Rusnock, P., \& George, R. (2007) Introduction. In: B. Bolzano, Selected Writings on Ethics and Politics (pp. 1-42) (P. Rusnock \& R. George, Trans.). Amsterdam, New York.

[18] Simons, P. M. (2013). Bolzano, Tarski, and the Limits of Logic. In: P. M. Simons, Philosophy and Logic in Central Europe from Bolzano to Tarski: Selected Essays (pp. 13-40). London: Springer.

[19] Sirůček, P., \& Jaroslav, Ś. (2019). Bernard Bolzano - Utopian Visionary. Acta Oeconomica Pragensia, 27(3-4), 95-104. DOI: https://doi.org/10.18267/j.aop.631.

[20] Synytsia, А. (2013). Аналітична філософія [Analytic Philosophy]. Lviv: ЛДУФК.

[21] Zdenek, V. D. (2008). Masaryk and the Austrian philosophical tradition: Bolzano and Brentano. Filosoficky Casopis, 56(3), 345-361. 